\title{
Characteristics Study of Street Vendors and Influence on Labor Absorption
}

\author{
Nurjannah ${ }^{1}$, Puti Andiny ${ }^{2}$ \\ \{nurjannah@unsam.ac.id, putiandiny@unsam.ac.id\} \\ ${ }^{1,2}$ Economic Faculty, Samudra University, Meurandeh, Langsa, Aceh, Indonesia
}

\begin{abstract}
One of the informal sector which absorb labour are street vendors. Given the limited employment opportunities in the formal sector, street vendors are the easiest option for survival. The main factor of this area to the informal sector selection is due to readily available, flexible in determining the time and place, just relying on local resources and the relatively small scale of business. This research is qualitative and quantitative. Methods of data collection through observation, interviews and a questionnaire distributed to 100 respondents street vendors who were at the city park, the road and sports stadiums. The results showed that street vendors using workforce 1-5 people with a wage of Rp. 10,000-Rp. 50,000 per day. Many vendors who were not satisfied in providing facilities and infrastructure provided by the government. There are some obstacles that they face are like the weather was bad so no many visitors, the demolition carried out by municipal police PP and site management business shanties irregular.
\end{abstract}

Keywords: Informal Sector, Street Vendors, Labor Absorption

\section{Introduction}

One of the informal sector which absorb labour are street vendors (PKL). Given the limited employment opportunities in the formal sector, street vendors are the easiest option for survival. The main factor of this area to the informal sector selection is due to readily available, flexible in determining the time and place, just relying on local resources and the relatively small scale of business. The presence of street vendors are not well organised or random placement and does not seem orderly. On the other hand, their presence is needed by the community. People still need them to meet the needs at an affordable price. Except that the presence of street vendors also have a significant impact on the supply of goods services and labour intensive thus reducing the burden on the government to provide jobs.

Langsa is one area that was faced with the phenomenon of street vendors, where the problems encountered are also not much different from other major cities in Indonesia. Structuring irregular often is the cause of a difference of opinion between street vendor's enforcement officers Langsa. On the other hand, the existence of informal sector businesses have also had a positive impact on the economy of Langsa, in addition to contributing to the increase in goods and services, this sector can also contribute to employment. This sector promising opportunities and possibilities for employment in the formal sector are not able to accommodate the entire workforce in Langsa. Given this, the government should also Langsa 
should facilitate the presence of street vendors with a clear legal basis so that they can still perform activities without any treatment evictions that make their operations disrupted. The existence of Langsa Qanun No. 14 of 2008 on Street Vendors is a form of attention and the seriousness of the government to solve all the problems that occurred on the sidewalk vendors. Another kind of care is mostly done by facilitating the various guidance and counselling as well as assistance in the form of financial and non-financial support to other production activities that will ultimately have a positive impact on revenue of street vendors and Economic Langsa.

\section{Literature Review}

\subsection{Definition of the Informal Sector}

The definition of the formal sector is as a sector consisting of business units that have obtained various economic protections from the government. While the informal sector is business units that do not get government protection and sectors that have not used government assistance or facilities even though the assistance is already available. The criteria used as a measure to distinguish between formal and informal sector businesses is the existence of accessibility to a facility provided by the government The informal sector comes to the surface because the formal sector does not provide sufficient scope so that economic activities take place outside the organized sector. The sector, which is mostly filled by underprivileged groups, is seen increasingly mushrooming in developing countries. Because its activities are seen as illegal, observers call this activity an underground economic activity or often called an underground economy (Rachbini and Hamid, 1994: 25).

\subsection{Characteristics of the Informal Sector}

According to [1] the informal sector has the following characteristics:

1) Business activities that are not well organized, because the emergence of business units does not use facilities or institutions available in the formal sector;

2) Generally do not have permission;

3) Pattern of irregular business activities, both in terms of location and working hours;

4) In general, government policies to help the weak economy do not reach this sector;

5) Business units that are easy to exit and enter from one sub-sector to another;

6) The technology used is still very simple;

7) Capital and business turnover are relatively small so that the scale of operations is also small;

8) Education needed to run a business does not require formal education because education is derived from experience while working;

9) In general, business units are included in class one enterprises and if employing workers usually comes from families;

10) Sources and business capital generally come from own savings or from unofficial financial institutions;

11) The production of certain services is consumed by the community.

\subsection{Definition of Street Vendors}


Street vendors are a term to call merchants who use carts. the term is often interpreted because there are five traders' legs. The five legs in question are two legs of the merchant plus three "legs" of the cart (which are actually three wheels or two wheels and one foot). Currently the term street vendor is also used for street traders in general.

Street vendors are traders who carry out their business activities within a certain period of time by using facilities or equipment that are easily moved, dismantled and used public facilities as their place of business. The Street Vendor phenomenon was indeed very alarming at first, related to its existence which was considered to damage the beauty of the city. This is because of their unlicensed, rundown, and irregular existence.

\subsection{Definition of Labor}

Definition of workforce contained in Law No. 25 of 1997 concerning Manpower, that is, every man or woman who is in and / or will do work, both inside and outside of work relationships to produce goods or services to meet the needs of the community.

According Sukirno (2005: 6) seen in terms of expertise and education, the workforce is divided into three groups, namely: first, recough labor is a labor force that is not educated or low education and does not have expertise in a job. Second, skilled workers are workers who have expertise from training or work experience. Third, educated workers are workers who have a high enough education and experts in certain fields of science.

The quantity of labor demanded will decrease as a result of wage increases. If the wage rate rises while other input prices remain, then the price of labor is relatively more expensive than other inputs. This situation encourages employers to reduce the use of labor that is relatively expensive with other inputs that are relatively cheaper in price to maintain maximum profits.

\section{Result And Discussion}

\subsection{Characteristics of Respondents}

1. Age description

In this study, the age is grouped into four range from 16 to 59 years. Based on the results of the descriptive analysis about the age of the respondents, from 100 vendors, 33 percent of them have age range from 27 to 37,29 percent have age between 38 to 48 years, 25 percent have age between 16-26 years, and 13 percent have age between 49 to 59 percent. Based on this data, it appears that the street vendors are productive youth who have high entrepreneur initiatives to live in self-employee life.

2. Education description

The last education could be as a standard of measurement for the skills and knowledge of respondents. The higher education that they have, the better skills and knowledge that they have. Based on the result of this study, 56 percent of the respondents have high school background, 30 percent of them have junior high school background, 13 percent of them have elementary school, and 1 percent of them refuse to answer. The result shows that the school background of high school is dominant, this low level of education is because of the lack of money support to continued their education to the higher level. However, they still have a great motivation to be an entrepreneur to make a better life.

3. The description of the ownership status 
Based on the result of the descriptive analysis of the ownership status of the vendors, found that 91 percent of them own their business themselves, while the rest, 9 percent, have partnership ownerships.

\subsection{The characteristic of street vendors activities}

1. Description of the starting the business

Based on the result of descriptive analysis, the street vendors started their business in different years. The result shows that the majorities, 60 percent, of the street vendors started their business in between year of 2011 and 2016, the reason was at that time the local government did not fully implemented the rules of Qanun no. 14 year of 2008. And 26 percent of them started their business in year of 2005 to 2010.

2. Description of the duration of the business life

Based on the result of descriptive analysis on the duration of their business per day, it shows that 65 percent of them open their vendors for about 5 to 9 hours a day, 18 percent of them open their vendors for about 10 to 13 hours a day, and 7 percent of them open it for about 1 to 4 hours a day. Most of them open their vendor at 10 am and close at $10 \mathrm{pm}$. Because the people start their activities at 10 am and end of the elementary school time.

3. Description of the types of merchandises

Based on the result of surveys performed in langsa city, specially at the three locations, we can mention the types of merchandises of the 100 street vendors. The result depicts that 45 percent of them offering the various food and beverages (culinary), 17 percent of them sell toys for kids, and 38 percent of them vary from apparel, fruits, etc.

4. Description of the ownership of land and the land rental fees

The ownership of the land or street vendor business in this study is grouped into three categories, which are lease, private, other parties. Based on the data analysis, the compositions of the ownership status of the land of the street vendors could be described. 75 percent of the street vendors have a leased land, because the land is owned by the local government, and 14 percent of them are private ownerships.

In their business activities, most of them run their business on the leased land, therefore they have to pay the lease fee. The lease fee paid by the street vendors 65 percent pays Rp. 5000 per day, 32 percent of them pays Rp. 5000 to 25000 per day, and 3 percent of them pays Rp. 25000 per day.

5. Description of the physical facilities

The result of the survey on 100 street vendors merchant located in three places in langsa city about physical facilities of street vendors, found that 49 percent of them have mobile vends. There are two types of vends, one is the roof top vends, and the other is roofless vends. Most of them own the roof top vends and no-stay merchants (mobile vends). 11 percent of them have semi permanent merchant and no-stay merchant. 10 percent of them have kiosk and stay merchants.

6. Description of cleanness and security fees

The other fees that they have to pay are the cleanness and security fees. Based on the result of analysis, found that 69 percent of them pay Rp. 3000 to Rp. 5000 per day for the cleanness fees.

The amount of security fees paid by them, 50 percent pay between Rp. 1000 and Rp. 2000 per day or below Rp. 3000.47 percent of them pay Rp. 3000 to Rp. 5000 per day, and 3 percent of them pay Rp. 5000 per day.

7. Description of the level income

The income acquired by the street vendors are vary. The variations of the income are influenced by the types of merchandises they offer, the ownership of the land, the facilities, the amount of customers, and so on. From the data analysis found that 59 percent 
of them have income of Rp.100000 to Rp. 500000, 24 percent of them have income of Rp. 600000 to Rp. 1000000,8 percent of them have income below Rp. 100000, and 9 percent of them have income above Rp. 1000000.

8. Description of the quality service

The services that they have are vary. After the analysis found that 53 percent of street vendor have a mobile service, that is they move from one place to another. 22 percent of them have the stay-service vendors, and 25 percent of them have semi stay-service vendors.

9. Description of the amount of capitals

In the business activities, capital is one of the inevitable thing to have in order to run the operational activities, like buying raw materials, paying employees wages, electric bills, transportation cost, etc. the capital could be obtained from self capital or debt in financial institutions. The aims are to increase the sales, scale up the production capacities.

Based on the result of the survey found that the street vendors in langsa city 28 percent of them owe the capital from the financial institutions, and the rest, 72 percent of them, their capital comes from their own pocket.

The debt comes from the financial institutions, bank and non-bank. From the result of analysis found that 19 percent of them have loan in Bank Rakyat Indonesia (BRI), Bank Muamalat, and others, and about 12 percent of them have loan in non-bank like leasing institutions, koperasi, and private lending. The amount of the loan that they have are between Rp. 1000000 and Rp. 5000000 and more than Rp. 20000000.

The working capital used by the street vendors in langsa city are vary based on the types of merchant and the size of the business. Based on the result of the data analysis, found that 41 percent of them have amount of capital of Rp. 1000000 to Rp. 5000000, 24 percent of them have amount of capital below Rp. 1000000, and 13 percent of them have Rp. 10000000 of working capital.

\subsection{The labor used by the street vendors}

Labor is a person who able to perform certain activities in order to produce goods and or services whether to fulfill own needs or others needs. The availability of the job vacancies is one of the main problem in improving the prosperity of people. Small business specially the street vendors have an important role in providing jobs.

Small business specially the street vendors have contributions in increasing the Production output and providing jobs in langsa city better than other types of business. It implies that small business like the street vendors have a huge opportunity to be developed to solve the unemployment problem. The result of the survey performed in langsa city depicts that the street vendors take labor between 1 to 5 persons. The average income of the labors is Rp. 10000 to Rp. 50000 per day. The income of the labors is depends on the sales per day.

\subsection{The role of the langsa city government in supporting the street vendors}

The evidence of the supports given by the langsa city government could be seen in the Qanun of langsa city no. 14 year 2008 about street vendors. The government through this Qanun, tries to solve the problems that the street vendors have. The other evidence of support from the government is providing the special spot, facilities, and seminar, training, and capital building. Government also provides financial and non-financial supports to improve their business activities. Based on the data analysis found that 54 percent of them confirm of disagree of the government's policy in providing the appointed street vendors spot, 14 percent of them unsatisfied, 5 percent of them very satisfied, and 27 percent of them satisfied. The other evidence of attention that the government gives is in providing the facilities. Based on 
the result of the survey found that 79 percent of them feel less satisfied and unsatisfied with the facilities provided, and 21 percent of them feel very satisfied.

In response to the government policy on street vendors, 76 percent of them feel less satisfied and unsatisfied, and 24 percent of them feel satisfied and very satisfied.

These statements are fit to the result of study performed by [2] stated that the implementation of the government policies in controlling the street vendors placement in langsa city felt not optimum. The street merchants still feel less satisfied with the local government policy because after relocation, the street merchant income has gone down. According to them, the new location is far away from the crowded people.

Based on the result of the survey, the preferred location that is figured to be more profitable according to the street merchants, 37 percent of them think the city park is more profitable, while the others have vary in view, like evening market spot, nearby coffee shops, at recreation spots like bamboo runcing park, etc. The basic reasons are that the location is strategic, crowded people, high people traffic (accessible), and concentrated market (aglomerasi), at such place, the merchants helping each others. Therefore the business activities going well and income is reached expectedly.

\subsection{Obstacles faced by the street vendors}

In running the business, every businessmen often facing obstacles that stall the objectives realization. For the street vendors in langsa city, they also face obstacles such as bad weather, financial condition, etc. 40 percent of them admitted that bad weather such as rainy day is one of the obstacles affecting low visitors and 16 percent of them said that obstacles come from the officer who repelled them from the present location.

\section{Conclusion}

1. Profile of the street vendors in langsa city

a. The street vendors in langsa city most of them age 27 to 37 years old and is the productive age in running a business and 56 percent of them have education background of high school.

b. The ownership of the business dominantly owned by themselves, therefore they run the business on their own and the ownership of vehicle is privatly.

c. Experiences of the street merchants will influence the ability in managing the business. Most of them having their business since year of 2011 and 2016 and open their business for 5 to 9 hours a day. Working hours is also will affect the income of the street vendors. More the work hours, higher the income they will get.

d. The types of merchandises they offer are vary, such as foods and beverages, like ice cream, various of juice, burger, etc.

e. The ownership of the land most of them are rent with fees less than Rp. 5000 per day or about Rp. 1000, Rp. 2000, and Rp. 3000.

f. The types of physical facilities they have are varies. Those are kiosk, semi permanent kiosk, tables, and vends. And most of them use the mobile vends, because its mobility.

g. The supply of merchandises comes mostly from prime market of langsa, and also from outer city, such as brastagi, medan, and banda aceh.

h. The preferred locations for running the business are along the pedestrian of the main street of the city, around the city park, and the recent appointed place. 
i. The fees that have to be paid by the street vendors are cleanness and security fees. The payment methods are varies, the amount is less than Rp. 5000. In the holiday, the visitors are greater in amount than the working day. Each street vendor serves 25-50 customers per day in average.

j. The income acquired by the street vendors are vary. The variations of income is influenced by the type of merchandises, the ownership of the land, cost, physical facilities, the amount of buyers, etc. the street vendors in langsa city have income between Rp. 100000 to Rp. 500000 per day.

$\mathrm{k}$. The loan for additional capital is acquired from financial institutions either bank or non bank. However, the street vendors are mostly use their own money as capital.

2. The usage of labors by the street vendors is between 1 to 5 persons. With this fact, could be depict that the small business are providing jobs for the community in the langsa city.

3. The role of local government in supporting the activities of street vendors has been implemented in the existence of Qanun Langsa City no. 14 year 2008. Eventhough, the street vendors are still feel that it is not quite helping. Most of the street vendors feel less satisfied with the government policies.

4. The obstacles faced by the street vendors in running their business, such as the rainy day so that less visitors, repelled by the officers, the government prohibited to take place in official events, and also from the non durable goods.

\section{Reference}

[1] M. P. Todaro, Economic Development in the Third World, Seventh. Jakarta: Erlangga, 2000.

[2] P. Andiny and A. Kurniawan, "Analysis of Street Vendor Income Before and After Relocation Program in Langsa City (Case Study on Street Vendors at Merdeka Field)," J. Samudra Ekon. ISSN 2549-4104, vol. 1, no. 2, pp. 192-203, 2017. 